STATE FORESTS, REGIONAL DIRECTORATE OF STATE FORESTS IN ZIELONA GORA, 1997, Analysis of business activity of the Regional Directorate of State Forests in Zielona Góra for the year 1997, published by: State Forests, Regional Directorate of State Forests, Zielona Góra.

REGIONALE PLANUNGSGEMEINSCHAFT LAUSITZ - SPREEWALD, 1998 Regional concept of securing raw materials for the region of Eużyce - Spreewald (grounds for regional planning), in proceedings of a German - Polish seminar on "Natural environment in the Spree-Neisse-Bober Euroregion", Zielona Góra.

SCHULTZE, K., 1998, Spatial development in the Spree-Neisse district with particular attention paid to brown coal mining, in proceedings of a German - Polish seminar on "Natural environment in the Spree-Neisse-Bober Euroregion", Zielona Góra.

UCHMAN, A., 1997, Extraordinary threats to the environment, in : information on the condition of the environment in the province of Zielona Gora in the years 1995 - 1996, published by: the State Inspectorate of Environmental Protection, Zielona Góra.

\title{
DETERMINATION OF DECISION RULES ON THE BASIS OF GENETIC ALGORITHMS
}

\section{ARITA TAKAHASHI, ARKADY BORISOV}

Genetic algorithms have widely been used in optimization tasks, and there are only a few works that use genetic algorithms to find rules. One of these studies is described [2] as follows: a set of solutions consists of various encoded rules:

$$
\begin{gathered}
\text { attribute } 1<\text { valueA; attribute } 2>=\text { value } B ; \\
\text { attribute } 3=\text { valueC. }
\end{gathered}
$$

One symbol string may encode several rules. One should foresee whether they will be combined with a conjunction or with a disjunction (conjunctive or disjunctive method [3]). The task of a genetic algorithm is to determine the preferences according to which a decision maker divided patterns into acceptable and unacceptable ones.

The present work deals with the following issues:

1. how to find the preferences by using only a small part of solution space;

2. how to find the preferences for fuzzy evaluations;

3. how to generate hypotheses for the best ideal and the worst ideal solutions.

By using the accumulated data base, the genetic algorithm should generate additional objects and rule weights for each object. The rules themselves will look as the hypotheses either affirmed or denied by the genetic algorithm.

If any rule is not to be taken into account, the genetic algorithm should indicate a low weight coefficient for this rule. If the rule should be taken into account to a certain extent, then for this rule the genetic algorithm should generate a large coefficient.

Thus, solutions will be formed from strings of length 15 ( 9 positions for structure and 6 - for rule weights). Then the weight coefficient for the $\mathrm{i}$-th rule (i-th criterion) could be
computed as follows: 


$$
\text { weight }_{i}=\frac{\text { digit }_{i}}{\operatorname{digit}_{1}+d i g i t_{2}+d i g i t_{3}+d i g i t_{4}+\operatorname{digit}_{5}+d i g i t_{6}}
$$

where digit $_{i}$ is the number in position $(9+i)$, digit ${ }_{1}$ is the number in position $(9+1), \ldots$, digit $_{6}$ is the number in position $(9+6)$. In the case when the last six symbols are zeros, i.e. "000000", the weight will be : weight $=1 / 6$.

All the six rules are connected with conjunction [3] for the selection mechanism:

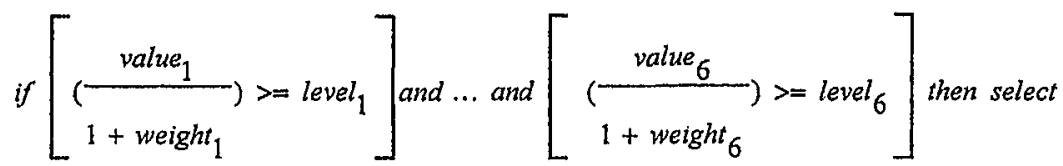

where level $_{l}$ is the value of a solution considered in the previous cycle, i.e. level $_{1}=\left(\text { value }_{1} /\left(1+\text { weight }_{1}\right)\right)_{\text {iteration- } 1}$, value $_{1}$ is the value that expresses the quality of a solution with regard to Rule1.

From the expressions it follows that the greater the meaning of weight ${ }_{i}$ is, the higher requirements are imposed on the objects by the $\mathrm{i}$-th rule which is to participate in forming the next generation, whereas if there is generated a small weight, the meaning of value $_{i}$ might also be small. The experiments have proved that coefficients converge to certain values.

\title{
REFERENCES
}

1. Goldberg D.E. (1989). Genetic Algorithms in Search, Optimization, and Machine Learning. Reading/MA, USA: Addison-Wesley.

2. Oliver J. Finding Decision Rules with Genetic Algorithms. (1994). AI Expert, March, 33-39.

3. Hwang C-L. and Yoon, K. (1981). Multiple Attribute Decision Making. Methods and Applications. Lecture Notes in Economics and Mathematical Systems, 186.

\section{NEIRONU TĪKLA UN LËMUMU KOKA SALĪDZINĀJUMS IZPLŪDUŠAS INFORMĀCIJAS APSTRĀDĒ}

\author{
ĒRIKS TIPĀNS \\ Intelektuālo Datortehnologiju Profilinstitūts \\ Rīgas Tehniskā Universitāte \\ Kalķ ielā 1, Rìga LV-1658, Latvija \\ Tālr.: +371 7089530 \\ Fakss: +3717820094 \\ E-mail: aborisov@egle.cs.rtu.lv
}

Darba mērķis bija salīdzināt neironu tīkla un lēmumu koka generēšanas algoritmu izplūdušas informācijas apstrādes uzdevumā. Izplūdušas informācijas apstrādei ir izstrādātas vairäkas pieejas - gan dažădu arhitektüru neironu tīkli, gan arī dažādi lēmumu koka indukcijas algoritmi. 